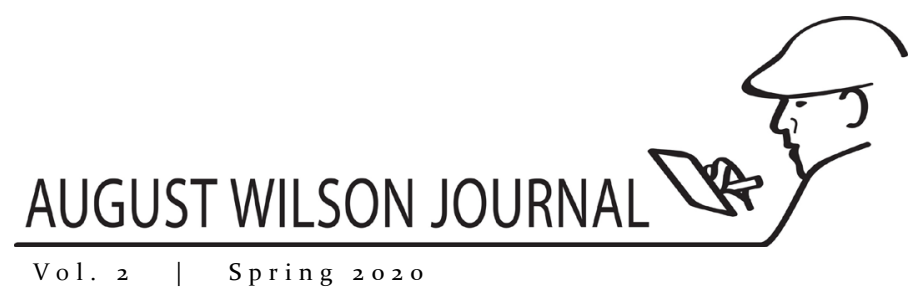

\title{
Stage Review of Arden Theatre's Production of Gem of the Ocean
}

\author{
Arden Theatre; Philadelphia, Pennsylvania \\ F. Otto Haas Stage \\ February 28-March 31, 2009 \\ Directed by James Ijames \\ By Ellen Bonds \\ Teaching Professor of English, Villanova University
}

\begin{abstract}
The City of Bones scene featured impressive special effects, but it was the characters' performances that "sold" the magical realism.
\end{abstract}

- Ellen Bonds

\begin{abstract}
A review of the Gem of the Ocean by August Wilson, staged at Arden Theatre in Philadelphia, Pennsylvania from February 28 through March 31, 2019.

Keywords

August Wilson, Gem of the Ocean, Ellen Bonds, Arden Theatre, Review, Aunt Ester, James Ijames, Music
\end{abstract}

From the set design to the direction to the actors' performances, the Arden Theatre's production of August Wilson's Gem of the Ocean conveyed the power of Wilson's play as it explored the dramatic tensions between the personal and the historical, harmony and discord, the legacy of slavery and the opportunity to find a sense of freedom.

The set design and sound effects that greeted the audience established the play's key themes. The stage was set just slightly off-center, protruding out in the shape of a ship's prow surrounded on both sides and in the front with pools of low-level water filled with black busts, both male and female. The sound of waves washing up on shore provided a sense of both calm and suspense as the audience waited in anticipation of what would come. Once the lights came up, Aunt Ester's home with its authentic appearing kitchen and, of course, a red door, provided a feeling of familiarity.

August Wilson's love of music was on full display from the ways that spiritual music, blues music, and overall musicality informed the production and the characters' performances. From the gospel-inspired/preacherly voice of Aunt Ester to the blues rhythm of Solly's speech. From Eli and Solly's syncopated storytelling of their days in the Underground Railroad to the call and response singing in "We went to the City of Bones." From the way that the play moved from piano to forte, building to a crescendo at the end of Act One and especially the City of 
Bones scene in Act Two, James Ijames' direction focused on infusing the production with the musical dimension essential to experiencing Wilson's work.

Although much of the cast had no prior experience acting in a Wilson play (with the exception of Brian Anthony Wilson as Solly Two Kings and Bowman Wright as Caesar), each performer delivered a worthy rendition of his/her character. The actors established their relationships with each other almost immediately and stayed in character even when exiting and re-entering the set. Zuhairah projected Aunt Ester's power most effectively in Act Two Scene One. Her performance grew stronger as the play developed. In fact, all the performances became more powerful as the actors developed their characters throughout the play.

The Prologue opened with Citizen's percussive entrance, the discordant exchange between him and Eli bursting the peace of Aunt Ester's house. Akeem Davis delivered a most outstanding performance, immediately establishing Citizen's desperation as Steven Wright fought (physically as well as verbally) to protect Aunt Ester's domain. Although this opening scene appeared a little rushed, Zuhairah in her Arden debut as Aunt Ester and Akeem Davis as Citizen created an intimacy that would continue throughout the play.

Brian Anthony Wilson as Solly entered Act One Scene One singing and maintained the perfect rhythm of his song in his speech. For this production, Solly's "stick" was more befitting of a king-a scepter with a globe on top that Wilson kept in his hand the entire time. Anthony Wilson's experience playing August Wilson's characters was obvious in the ease of his delivery-a true Wilson warrior.

Danielle Leneé in her Arden debut as Black Mary contributed a similarly worthy performance creating a sense of her character's steadfast devotion to Aunt Ester that evolves from obsequiousness to agency. Leneé sustained perfect rhythm in her dialogue with all the characters and added layers to her depiction as she kept true to Black Mary's character.

Brian McCann as Selig harmonized with the other characters, matching their accented cadences with his own. Bowman Wright as Caesar employed the metrics of his speech to accompany his gestures and to expose Caesar's apparent lack of self-awareness regarding his hypocrisy.

At times, the characters communicated most effectively without rhythmic speech or song. In Act One Scene Three, Anthony Wilson and Steven Wright signaled their disapproving responses to Caesar through their facial expressions and gestures. Akeem Davis dramatized Citizen's vulnerability with his eyes, his silent pauses. He and Zuhairah as Aunt Ester did not need to speak in order to dialogue with each other. Their seemingly telepathic connection came across most effectively in Act One Scene Five when Citizen confesses. In Act Two Scene One, Zuhairah's and Leneé's comic timing in both speech and looks infused the two pennies bit with Wilson's humor, an essential element of Wilson's drama that does not always translate off the page

The musical dimension of the play continued in Act Two. For example, in Scene Two Eli and Solly recount their stories about the Underground Railroad as if they are musicians playing in a jazz set. Their recitation of the W.C. Bryant poem demonstrated that they are perfectly capable of offering another way of speaking but choose to sing their speech out of the African tradition, the legacy of the ancestors.

The City of Bones scene featured impressive special effects, but it was the characters' performances that "sold" the magical realism. Here, the production built in intensity, creating a crescendo of sights and sounds. The actors' expressions, gestures, their call and response singing "We're going to the City of Bones," and "Remember Me" combined to create the high point of the performance.

Overall, only a few minor details could have been improved. As mentioned above, the opening scene appeared a little rushed. At first, some of the accents appeared affected, but they became more natural as the play continued. I credit the actors' delivery more so than 
the audience's ear. In Act Two Scene Three, Aunt Ester's response to Black Mary, "What took you so long," would have benefitted from one more paused beat.

In his "Director's Note," James Ijames shares the ways that he relates personally to Wilson's play: "Had I been born property in 1865, in [my] thirty-ninth year of life I could still be grappling with what freedom means and all the massive change that comes with that freedom."

Ijames, Thom Weaver (set design), Levonne Lindsay (Costume Designer), Daniel Ison (Sound Designer), and all the actors produced a most powerful exploration of the complex, nuanced meaning of freedom as August Wilson articulates it in Gem of the Ocean.

\section{Work Cited}

Wilson, August. Gem of the Ocean. The August Wilson Century Cycle. Theatre Communications Group. 2007.

\section{Author Bio}

Dr. Ellen Bonds is Assistant Professor of English at Villanova University. She holds a B.A. from the University of Louisville, an M.A. from West Chester University, and a Ph.D. from Lehigh University.

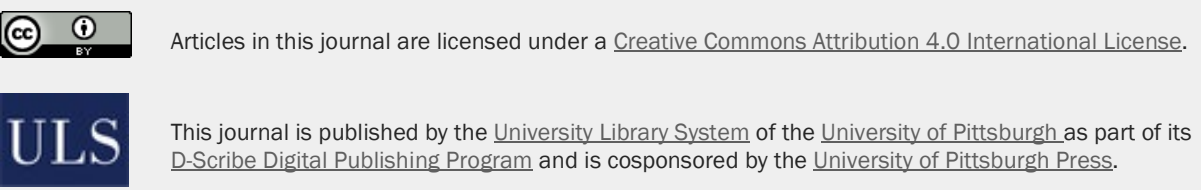

